The Agriculturists 13(1): 127-132(2015) ISSN 2304-7321 (Online), ISSN 1729-5211 (Print)

A Scientific Journal of Krishi Foundation

Indexed Journal

\title{
Efficacy of Herbicides in Controlling Weeds in Mungbean (Vigna radiata L. Wilczek) Field
}

\author{
Shamima Aktar ${ }^{1 *}$, M. A. Hossain ${ }^{1}$, M. R. Amin², F. Khatun ${ }^{3}$ and A. Begum ${ }^{4}$ \\ ${ }^{1}$ Pulse Research sub-station, ${ }^{2}$ On-Farm research Division, ${ }^{3}$ Oilseed Research Centre and ${ }^{4}$ Entomology \\ Division, Bangladesh Agricultural Research Institute (BARI), Gazipur-1701, Bangladesh \\ *Corresponding author and Email: shamima.prc@gmail.com
}

Received: 20 February $2015 \quad$ Accepted: 06 June 2015

\begin{abstract}
A field experiment was conducted at the Pulse Research Centre of Bangladesh Agricultural Research Institute, Ishurdi, Pabna during Kharif-II season of 2010 to evaluate the efficacy of five herbicides for controlling weeds associated with mungbean (BARI Mung-6). The five herbicides such were: Paraxon (27.6\% WV Paraquat dichloride salt), M-clor 5G (Butaclor), Topstar 40 WP (40\% Oxadiargyl), Hammer 24 EC (Carfentrazone ethyl), and Panida 33 EC (Pendimethalin) with one control (no herbicide and also no weeding). Weed was collected species wise during weeding at 40 days after sowing from $1 \mathrm{~m}^{2}$ area of each plot and oven dried to estimate weed growth. Among the herbicides, Panida performed the best for reducing the number and dry weight of weeds. The maximum reduction of weed population, the highest weed control efficiency, seed yield $\left(1222 \mathrm{~kg} \mathrm{ha}^{-1}\right)$, and maximum economic benefit were also obtained in the treatment receiving Panida $33 \mathrm{EC} @ 2 \mathrm{ml} \mathrm{L}^{-1}$.
\end{abstract}

Keywords: Herbicides, efficacy, controlling weeds, mungbean

\section{Introduction}

Mungbean (Vigna radiata L. Wilczek) is the second most important pulse crop grown in Bangladesh in respect of acreage and production. It covered an area of 35203 hectares with annual production of 25,000 metric tons during 20122013 growing season (BBS, 2014). It is a nutritious food item with high content of protein (20-25\%), minerals (4\%) and carbohydrate (46$51 \%$ ) (BARI, 2008). Due to rapid growth and early maturity, the crop fit well in rice-based cropping system, resulting in the increase of small landholders' income and improvement of soil fertility (Nsoukpoe-Kossi et al., 1999).

However, one of the major constraints in mungbean production is weed competition. The loss of mungbean yield due to weeds ranges from $65.4 \%$ to $79.0 \%$ (Shuaib, 2001; Dungarwal et al., 2003). Besides causing crop losses, weeds creating competition for nutrients, space, water etc. reduce the crop yield and the quality of produce hence; reduce the market value of the turnout (Arif et al., 2006). As most mungbean is sown as broadcast, it is difficult to weed them and therefore, farmers do not weed at all in the mungbean field. In most cases, one to two weeding are necessary. For the success of summer production of mungbean in Bangladesh, the role of weeding needs to be emphasized (FAO/UNDP, 1984). Weed competition with mungbean persisting for 20-30 days after emergence was very critical and prolonged competition resulted in substantial yield reduction (Naeem et al., 1999). There are 
different weed control methods like manual, mechanical and chemical (herbicide) etc. But manual and mechanical weeding are laborious, time consuming and costly. Today, some herbicides are available in the market which is capable to control weeds in crop fields. Weed competition is maximal during the early stage of growth. However, the most critical period of weed competition varies with the growth behavior of the crop variety, environmental conditions, stage of growth, weed species presence and intensity of weed infestation.

Weed control is a major problem in legumes, because of slow growth of seedlings and hence most of the fast growing weeds smother pulse crops. Weed competition is very severe during rainy period, particularly at early stages (30 to 45 days after sowing) of the legume crops and hence early weed control is essential. Herbicides inhibit weed growth for considerable period after their application as reported by Gupta (2003). But little information is available regarding the herbicide(s) that is actually suitable for either pre-sowing or post-sowing application in mungbean. Therefore, the present research work was carried out to find out the suitable herbicides for controlling weeds associated with mungbean by pre or post-sowing application and to evaluate the relative efficacy of herbicides on growth, yield and profitability of mungbean.

\section{Materials and Methods}

The field experiment was conducted at research farm of Pulse Research Centre of Bangladesh Agricultural Research Institute, Ishurdi, Pabna during Kharif-II season of 2010. The trial consisted of six herbicides such as $\mathrm{T}_{1}=$ Paraxon (27.6\% WV paraquat dichloride salt) @ $2.0 \mathrm{ml}$ $\mathrm{L}^{-1}$ water, $\mathrm{T}_{2}=\mathrm{M}$-clor $5 \mathrm{G}$ (Butaclor)@ $2.5 \mathrm{~g} \mathrm{~L}^{-1}$ water, $\mathrm{T}_{3}=$ Topstar $40 \mathrm{WP}$ (40\% Oxadiargyl) @ $1.0 \mathrm{~g} \mathrm{~L} \mathrm{~L}^{-1}$ water, $\mathrm{T}_{4}=$ Hammer $24 \mathrm{EC}$ (Carfentrazone ethyl) @ $1.0 \mathrm{ml} \mathrm{L}^{-1}$ water, $\mathrm{T}_{5}=$ Panida 33 EC (Gluphosinate-ammonia) @ $2.0 \mathrm{ml}$ $\mathrm{L}^{-1}$ water, and $\mathrm{T}_{6}=$ unweeded control. The experiment was laid out in randomized complete block design with 3 replications. The unit plot size was $5 \mathrm{~m} \times 4 \mathrm{~m}$. Seeds were sown on the 26 August, 2010. The variety BARI mung-6 was grown with a fertilizer dose @ 20:40:20 kg ha ${ }^{-1}$ of $\mathrm{N}: \mathrm{P}_{2} \mathrm{O}_{5}: \mathrm{K}_{2} \mathrm{O}$ in the form of urea, single superphosphate, muriate of potash, respectively as basal application during final land preparation. The seeds were sown@25 kg ha ${ }^{-1}$ in furrows at $30 \mathrm{~cm} \times 10 \mathrm{~cm}$ spacing at a depth of 2 to $3 \mathrm{~cm}$ below the soil surface. Herbicides were applied in two leaf stage of mungbean as dose mentioned in treatment.

Two irrigations were applied, one at immediately after seed sowing and another at flowering stage (35 DAS) of crop. Intercultural operations such as mulching, thinning, applying insecticides were done as and when necessary. Weed samples were taken at 40 DAS from $1 \mathrm{~m}^{2}$ area in each plot using quadrate and weed population and dry weights were recorded. The pod of mungbean was harvested twice at 21 October and again at 9 November, 2009, respectively. The crop growth, weed dry weight and weed control efficiency were recorded at 40 days after sowing of the crop. Weed control efficiency (WCE \%) and intensity of weed infestation were calculated following Kundu et al. (2009) as:

$\mathrm{WCE}=\frac{\mathrm{X}-\mathrm{Y}}{\mathrm{X}}$

Where, $X=$ Number or dry weight of weeds in unweeded plot and $\mathrm{Y}=$ Number or dry weight of weeds in treated plot.

Intensity infestation $=$

Absolute density of a given weed species/unit area $\left(\mathrm{m}^{2}\right)$

Absolute density of the crop plant/unit area $\left(\mathrm{m}^{2}\right)$

Data on yield and yield contributing characters were recorded from five randomly selected plants from each plot and grain yield $\left(\mathrm{kg} \mathrm{ha}^{-1}\right)$ was recorded from the whole plot. Data were statistically analyzed using MSTAT-C program and the treatment means were compared using LSD at $5 \%$ by Duncan's Multiple Range Test (DMRT) according to Gomez and Gomez (1984). All types of variable production cost were recorded to find out the cost and return. 
Economic analysis with respect to gross margin was calculated to evaluate the profitability of different treatments.

\section{Results and Discussion}

3.1. Grain yield and yield components

Yield and yield contributing characters of mungbean varied significantly due to the application of herbicides (Table 1). The tallest plants $(52.53 \mathrm{~cm})$ were obtained from $\mathrm{T}_{5}$ and the height was minimal $(40.13 \mathrm{~cm})$ in unweeded control treatment $\left(\mathrm{T}_{6}\right)$ as weed suppressed the growth of mungbean plants. Different weed control methods significantly affected plant height of mungbean as reported by Chattha et al. (2006). Number of pods per plant among the herbicidal treatments was statistically similar but unweeded control produced the least. Chattha et al. (2006) observed that the number of pods per plant was significantly affected by different weed control methods. Seeds per pod and 1000seed weight are varietal characters and hence did not differ significantly among the herbicides used as treatment.
The height seed yield (1222 $\left.\mathrm{kg} \mathrm{ha}^{-1}\right)$ was obtained from $\mathrm{T}_{5}$ followed by $\mathrm{T}_{2}\left(1088 \mathrm{~kg} \mathrm{ha}^{-1}\right)$. The yield produced in the treatments $\mathrm{T}_{3}(962.7$ $\left.\mathrm{kg} \mathrm{ha}^{-1}\right), \mathrm{T}_{1}\left(906.7 \mathrm{~kg} \mathrm{ha}^{-1}\right)$, and $\mathrm{T}_{4}(883.3 \mathrm{~kg} \mathrm{ha}$ $\left.{ }^{1}\right)$ did not differ statistically. Application of weedicides might control the growth of weeds that facilitated proper crop growth led to produce higher yields. The lowest seed yield $(741.7 \mathrm{~kg}$ $\mathrm{ha}^{-1}$ ) was recorded in unweeded control plot $\left(\mathrm{T}_{6}\right)$ might be due to the weed infestation disturbed proper utilization of growth resources by the crop plants. The highest yield increment $(65 \%)$ over the unweeded control was recorded in Panida applied plot followed by M-Clor (47\%). The increment was $30 \%$ in Topstar, $23 \%$ in Paraxon and Hammer the least $(19 \%)$. Weed infestation in mungbean is one of the main causes of low yield per hectare against the potential yield and uncontrolled weeds can reduce mungbean yield by 46,69 and $35 \%$ as reported by Pandey et al. (2003), Yadav et al. (2005) and Raman et al. (2005), respectively.

Table 1. Yield and yield contributing characters of mungbean in herbicidal weed control

\begin{tabular}{lccccc}
\hline $\begin{array}{l}\text { Treatments } \\
\text { (Herbicides) }\end{array}$ & $\begin{array}{c}\text { Plant height } \\
(\mathrm{cm})\end{array}$ & $\begin{array}{c}\text { Pods plant }^{-1} \\
(\text { no. })\end{array}$ & $\begin{array}{c}\text { Seeds pod } \\
\left(\text { no. }^{-1}\right.\end{array}$ & $\begin{array}{c}1000 \text {-seed wt. } \\
(\mathrm{g})\end{array}$ & $\begin{array}{c}\text { Seed yield } \\
\left(\mathrm{kg} \mathrm{ha}^{-1}\right)\end{array}$ \\
\hline $\mathrm{T}_{1}=$ Paraxon & $46.87 \mathrm{c}$ & $8.6 \mathrm{ab}$ & 9.66 & 46.13 & $\begin{array}{c}906.7 \mathrm{bc} \\
(22.24)\end{array}$ \\
$\mathrm{T}_{2}=$ M-clor & $49.47 \mathrm{~b}$ & $8.6 \mathrm{ab}$ & 9.33 & 46.00 & $\begin{array}{c}1088.0 \mathrm{~b} \\
(46.70)\end{array}$ \\
$\mathrm{T}_{3}=$ Topstar & $49.27 \mathrm{~b}$ & $9.0 \mathrm{a}$ & 9.33 & 46.13 & $\begin{array}{c}962.7 \mathrm{bc} \\
(29.79)\end{array}$ \\
$\mathrm{T}_{4}=$ Hammer & $48.80 \mathrm{~b}$ & $8.0 \mathrm{~b}$ & 9.66 & 46.40 & $\begin{array}{c}883.3 \mathrm{~cd} \\
19.09)\end{array}$ \\
$\mathrm{T}_{5}=$ Panida & $52.53 \mathrm{a}$ & $9.3 \mathrm{a}$ & 10.00 & 47.60 & $\begin{array}{c}1222.0 \mathrm{a} \\
(64.75)\end{array}$ \\
$\mathrm{T}_{6}=$ Unweeded & $40.13 \mathrm{~d}$ & $7.0 \mathrm{c}$ & 9.00 & 45.00 & $\begin{array}{c}741.7 \mathrm{~d} \\
\text { Control }\end{array}$ \\
\hline $\mathrm{CV}(\%)$ & 1.75 & 4.67 & 6.93 & 2.64 & 8.60 \\
\hline
\end{tabular}

Figures in parenthesis are percent of unweeded control values 


\subsection{Effect of herbicide on weed population and weed dry weight}

Different weedicides reduced the growth of weeds in mungbean. The highest weed population (900) was recorded in unweeded control treatment (Fig. 1) which resulted the highest dry matter production (Fig. 2) might be due to the unchecked growth of weeds at all stages of crop growth. Among the different herbicides, the highest weed population (754) was counted in Hammer applied plot which was statistically similar with Topstar (741) and Paraxon (738). The lowest population (592) was observed in the plots where Panida was applied.
Significant differences due to weed control treatments were recorded in weed biomass. The dry matter weight by the application of Hammer, Topstar, Paraxon and M-clor were 243, 239, 238 and $231 \mathrm{~g} \mathrm{~m}^{-2}$, respectively but Panida was the lowest $\left(191 \mathrm{~g} \mathrm{~m}^{-2}\right)$. According to Bhanumurthy and Subramanian (1989) weed dry matter is a better parameter to measure the competition than the weed number. The percentage of reduction in weed dry weight per $\mathrm{m}^{2}$ did not differ among Hammer (16.20\%), Topstar (17.58\%) and Paraxon $(17.93 \%)$ but Panida performed better by reducing $34.13 \%$ dry weight over the unweeded control treatment.

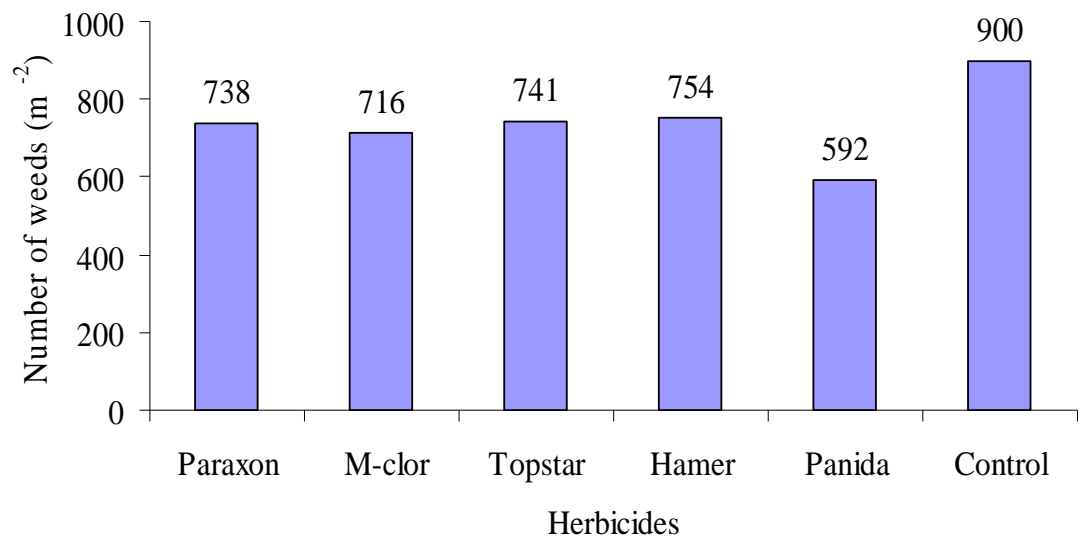

Fig.1. Performance of different weedicides for controlling weeds

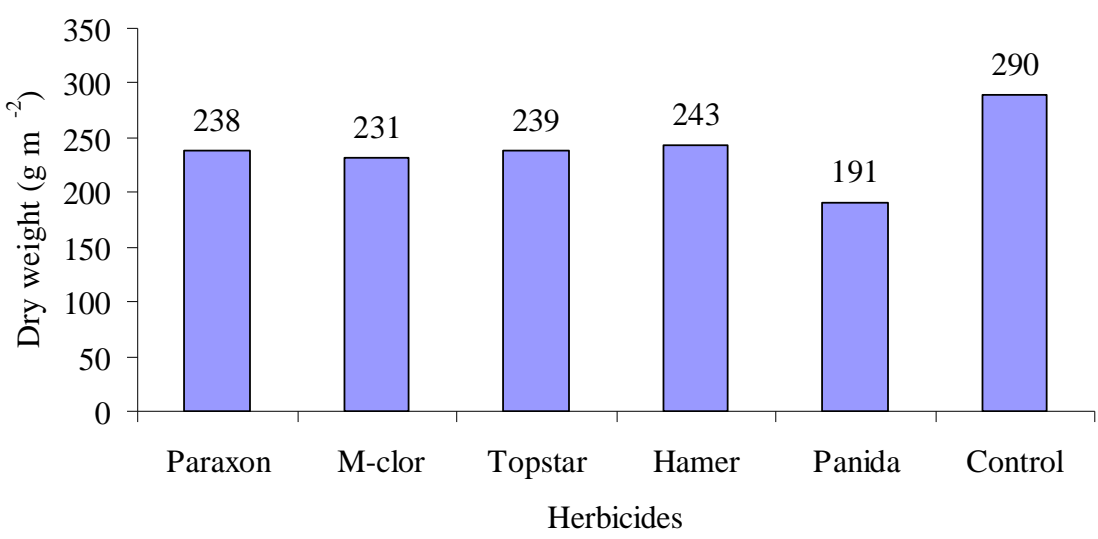

Fig.2. Dry matter accumulation by weeds at 40 days after sowing 
Table 2. Weed control efficiency of herbicides and intensity of weed infestation

\begin{tabular}{lcc}
\hline $\begin{array}{l}\text { Treatments } \\
\text { (Herbicides) }\end{array}$ & Weed control efficiency (\%) & Intensity of infestation \\
\hline $\mathrm{T}_{1}=$ Paraxon & 17.93 & 26.70 \\
$\mathrm{~T}_{2}=$ M-Clor & 20.34 & 24.38 \\
$\mathrm{~T}_{3}=$ Top star & 17.58 & 26.86 \\
$\mathrm{~T}_{4}=$ Hammer & 16.20 & 27.83 \\
$\mathrm{~T}_{5}=$ Panida & 34.13 & 20.93 \\
$\mathrm{~T}_{6}=$ Control & 00.00 & 00.00 \\
\hline
\end{tabular}

Table 3. Agro-economic performance of herbicidal weed control

\begin{tabular}{lcccc}
\hline \multicolumn{1}{c}{$\begin{array}{c}\text { Treatments } \\
\text { Herbicides })\end{array}$} & $\begin{array}{c}\text { Grain yield } \\
\left(\mathrm{Kg} \mathrm{ha}^{-1}\right)\end{array}$ & $\begin{array}{c}\text { Total variable cost } \\
\left(\mathrm{Tk.} \mathrm{ha}^{-1}\right)\end{array}$ & $\begin{array}{c}\text { Gross return } \\
\left(\mathrm{Tk} . ~ h a^{-1}\right)\end{array}$ & $\begin{array}{c}\text { Gross margin } \\
\left(\mathrm{Tk.} \mathrm{ha}^{-1}\right)\end{array}$ \\
\hline T1= Paraxon & 906.7 & 35040.5 & 72536.0 & 37495.5 \\
T2= M-Clor & 1088.0 & 37760.0 & 87040.0 & 49280.0 \\
T3= Top star & 962.7 & 35080.5 & 77016.0 & 41935.5 \\
T4= Hammer 24 EC & 883.3 & 34721.5 & 70696.0 & 35974.5 \\
T5=Panida & 1222.0 & 39270.0 & 97760.0 & 58490.0 \\
T6=Unweeded Control & 741.7 & 30566.0 & 59336.0 & 28770.5 \\
\hline
\end{tabular}

Price: Urea $=$ Tk. $6.00 \mathrm{~kg}^{-1}, \mathrm{TSP}=$ Tk. $47.00 \mathrm{~kg}^{-1}, \mathrm{MOP}=$ Tk. $37.00 \mathrm{~kg}^{-1}$, Labour $=$ Tk. 120.00 per man-day, Mungbean seed $=$ Tk. $80.00 \mathrm{~kg}^{-1}$

\subsection{Weed control efficiency (\%) and intensity of weed infestation}

Weed control efficiency of herbicides and intensity of infestation of weeds have been presented in Table 2 . The highest weed control efficiency $(34.13 \%)$ was found in $\mathrm{T}_{5}$ (Panida) and the lowest efficiency (16.20\%) was recorded in $\mathrm{T}_{4}$ (Hammer). Meanwhile, the lowest intensity of infestation (20.93) was recorded in $\mathrm{T}_{5}$ (Panida) and the highest (27.83) was in $\mathrm{T}_{3}$ (Hammer).

\subsection{Economics}

Total variable cost varied among the treatments due to the addition of price of herbicides, its application cost and cost of additional yield harvest (Table 3). The total variable cost was the lowest in unweeded control. The highest gross return was calculated in the treatment $\mathrm{T}_{5}$ (Tk. $97760 \mathrm{ha}^{-1}$ ) followed by $\mathrm{T}_{2}$ (Tk. $87040 \mathrm{ha}^{-1}$ ) and $\mathrm{T}_{3}\left(\mathrm{Tk} .77016 \mathrm{ha}^{-1}\right.$ ). The lowest return was in control $\mathrm{T}_{6}\left(\right.$ Tk. $\left.59336 \mathrm{ha}^{-1}\right)$. Similar trend was also observed in case of gross margin in treatment $\mathrm{T}_{5}$ (Tk. $\left.58490 \mathrm{ha}^{-1}\right)$.

\section{Conclusions}

Weed population, weed biomass and seed yield of mungbean differed significantly due to chemical weed control treatments. The performance of other herbicides except Panida seemed to be identical in controlling weeds that infested the mungbean field. The highest weed control efficiency and the lowest weed infestation were observed in Panida applied plot. 
This treatment $\left(\mathrm{T}_{5}\right)$ out yielded other treatments in terms of number of pods per plant, number of seeds per pod, 1000 grain weight, grain yield and net benefit. Therefore, application of Panida in mungbean field seems to be promising in keeping the field weed free during the critical growth period and ensuring higher seed yield.

\section{References}

Arif, M., Khan, M., Akbar, H., Sajjad and Ali, S. 2006. Prospects of wheat as a dual purpose crop and its impact on weeds. Pakistan J. Weed Sci. Res., 12(2): 13-17.

BARI (Bangladesh Agricultural Research Institute). 2008. Mungbean cultivation in Bangladesh. Pulse and oilseed research strengthening project. Bangladesh Agril. Res. Inst. Joydebpur, Gazipur-1701. 64 p.

BBS (Bangladesh Bureau of statistics), 2014. Statistical yearbook of Bangladesh. Statistics and informatics division. Ministry of planning. Government of the people's republic of Bangladesh. Dhaka.133 p.

Bhanumurthy V. B. and Subramanian, N. S. 1989. Adaptation of new parameters, grain yield competition for weed control study. Indian J. Agril. Sci., 59:800-801.

Chattha, M. R., Jamil, M. and Mahmood, T. Z. 2006. Yield and yield components of mungbean as affected by various weed control methods under rain-fed conditions of Pakistan. Intl. J. Agril. Biol., 15608530/2007/09-1-114-119. ttp://fspublishers.org.

Dungarwal, H. S., Chaplot, P. C. and Nagda, B. L. 2003. Chemical weed control in mungbean (Plaseolus radiatus L.). Indian J. Weed Sci., 35: 283-84.

FAO/UNDP. 1984. FAO/UNDP project. Strengthening the agriculture extension service. Kharanbari, Farmgate, Dhaka, Bangladesh. 29-50 pp.
Gomez, K. A. and Gomez, A. A. 1984. Statistical procedure for agricultural research. $2^{\text {nd }}$ edition. International Rice Res. Institute, John Wiley and Sons. 680 p.

Gupta, O.P. 2003. Weed management: Principles and Practices. $2^{\text {nd }}$ edition. Agribios India. 11-24 \& 77-101 pp.

Kundu, R., Bera, P. S. and Brahmachari, K. 2009. Effect of different weed management practices in summer mungbean (Vigna radiata L.) under new alluvial zone of West Bengal. J. Crop Weed, 5(2): 117-121.

Naeem, M. and Ahmed, S. 1990. Critical period of weed competition with the growth of mungbean. Pakistan J. Biol. Sci., 2 (4): 1608-1610.

Nsoukpoe-Kossi, C. N., Aglvanov, A. G., Veeranjaneyulu, K. and Leblane, R. M. 1999. Protective action of abscisic against the inhibition of photosynthesis of barley leaves by bisulphate. Photosynthetica, 36: 51-60.

Pandey, J. and Mishra, B. N. 2003. Effects of weed management in rice wheatmungbean cropping system on weeds and yields of crops. Annals Agric. Res., 23: 646-50.

Raman, R. and Krishnamoorthy, R. 2005. Nodulation and yield of mungbean (Vigna radiata $\mathrm{L}$.) influenced by integrated weed management practices. Legume Res., 28: $128-30$.

Shuaib, O. S. B. 2001. Critical period for weed competition in green gram. Univ. Aden. J. Nat. Appl. Sci., 5: 11-18.

Yadav, V. K. and Singh, S. P. 2005. Losses due to weeds and response to pendimethalin and fluchloralin in varieties of summer sown Vigna radiate. Annals Pl. Protect. Sci., 13: 454-7. 